\title{
Turkish Religious Identity in Bulgaria in the Last Twenty-Four Years (1989-2013)
}

\author{
Mila Maeva
}

\begin{abstract}
Balkan Ethnology Department, Institute of Ethnology and Folklore Studies with Ethnographic Museum, Bulgarian Academy of Sciences mila_maeva@yahoo.co.uk
\end{abstract}

\begin{abstract}
The article is focused on the religious identity of the Turkish minority in Bulgaria during the last 24 years presented in three main trends: the process of re-Islamization or revitalization of Islam, rejection of religion as an ideology (atheistic ideas), and situational attitude related to the manifestation or hidden religious beliefs and behaviour according to the given situation or interlocutor. The contemporary Turkish confessional identity could be understandable in light of the communist past and the so called "Revival process". Even though there was a strong process of "re-Islamization" after 1989, the majority of Turks in Bulgaria are secularly disposed. The fundamental reason for this is the atheistic attitude of the post-modern Bulgarian society as a whole. The overlapping of ethnic and religious identity is primary for the representatives of that minority. The primordial markers such as ethnic origin and cultural traditions are more important than global "Umma".
\end{abstract}

Key words: Islam, Turks, Bulgaria, identity

In Bulgarian science, the Turkish community has long been the centre of researcher's attention. Settled in 14th century during the Ottoman conquest of the Balkans, ${ }^{1}$ it comprises 588,318 people or around $8.8 \%$ of the whole population. ${ }^{2}$ The biggest part of Turkish population is made up of Sunni Muslims of the Hanafite School and the Shià community counts just 27,407 people. ${ }^{3}$ The Turkish communities are mostly rural. They are concentrated in a few Bulgarian regions such as Kurdjali (101,116 people) in Southern Bulgaria, Razgrad (71,963 people) and Shumen $(59,551)$ in Northeast Bulgaria, Burgas $(58,636)$ in Eastern Bulgaria etc.

Before proceeding, it is necessary to make some clarifications. Most researchers use the name Alevi or Aliani community for the Shià Muslims in Bulgaria. ${ }^{4}$ Other researchers describe them as "heterodox/unorthodox Muslims" (Aleksiev 2012; Georgieva 1991; 
Gramatikova 2011; Karamihova 2002; Mikov 1997, 2005). According to my field studies in Northern and Southern Bulgaria, the representatives of the community identified themselves differently. For example, most people from the Bivolyane village in Kardzhali region and from the Shiroka Polyana village, Haskovo region (Southern Bulgaria) identified themselves as Bektashi or Kazilbashi while Turks in the Mogilets and Yablanovo villages (North-eastern Bulgaria) - as Alevi or Aliani (AIMIR No. 3321/19. 02.2004). Moreover, the people from those communities revealed small practical and ideological differences in the local religious rituals.

The role of religion in contemporary Turkish self-determination is significant as during the 45 years of communist regime in the country the communist government used a wide range of radical social mechanisms aspiring to alienate the community from Islamic norms and practices. The policy of the Bulgarian communist party (BCP) towards the Turkish minority in the country after it came to power in 1944 changed many times and was in compliance with the lack of a well-defined course from the preceding period after the restoration of the Bulgarian State in 1878. For that reason, it is not possible to talk about a hard-line policy towards Bulgarian Turks, as well as towards other minority groups such as the Gypsies, Bulgarian Muslims (Pomaks), Jews, Armenians etc. In general, the ethnic policy of the BCP swung like a pendulum from the provision of rights to periodical waves of emigration to the attempts for accession and enforced assimilation (Eminov 1990; Poulton 1993).

Leading by ideology of scientific atheism, the communist regime in Bulgaria perceived Islam as the most serious obstacle "in the path of Turkish integration". Therefore, the BCP leaders endeavoured to overcome confessional differences in the country. 1958 they accepted the thesis against religious fanaticism and for imposition of atheistic education. Party committees and social organizations were required to conduct such propaganda among the Turkish population to "undermine the religious view". The first measures were administrative. April 7, 1960 Politburo ordered the Committee of Religious Affairs "to provide zoning of settlements with the Turkish population in 500 regions of Bulgaria and those with Moslem religion in 80 regions." Persons loyal to the state authorities were appointed for all religious people and they were subjected to special 
ideological training. After raising the slogan "every imam - a member of Security Agency" the Bulgarian state started paying monthly wages ranging from 300 to 450 leva per religious official (Trifonov 1991: 10). At the beginning of $1960 \mathrm{~s}$, the Central Committee of BCP held a meeting concerning "condition and tasks of atheistic propaganda among the Turkish population." It assessed that the atheistic propaganda was in danger and not successful. Until the beginning of 1960s, 2/3 of the Turkish population preserved their faith, $95 \%$ of young people contracted religious marriages, $99 \%$ of children were circumcised. BCP decided to impose new administrative measures and propaganda activities to eliminate the role of religion in public life and family, to "clear the domestic traditions from religious content" and enforced "the socialist traditions and rituals" (Yalamov 2002: 328).

1959 a special directive by the Ministry of Public Health and Welfare ordered circumcision to be performed by doctors while the ritual was to be abandoned by the Muslims. In the same year, a campaign against veils also started. It was forbidden for Turkish women to wear headscarves and shalwars in public. Limiting the Islamic norms, mixing religious and communist ideology inevitably affected the religiosity of the Bulgarian Turks. As a result of those measures, 1987 BCP found that young Turkish women were already dressed in a modern way and they wore shalwars mainly at home. "We also have a decisive breakthrough in the fight against the circumcision of children. In many villages and municipalities no children have been circumcised in the recent years."

On the other hand, the communist regime initiated a process of imposing of new civil rites related to the naming of new-born children, weddings, funerals and traditional festivals and fairs. "The agents of State Security services observe people visiting mosques or participating in the Islamic rituals. New mosques are not being constructed and a gradual process of promoting new commemorative monuments on graves is underway." 6 All described trends can be assessed as a desire to strengthen the atheistic influence of acculturation and to construct a common "socialist culture" for all ethnic groups in the country.

The most impressive assimilation - the so called 'Revival process' (Vyzroditelen proces) happened between 1984 and 1989 and it was 


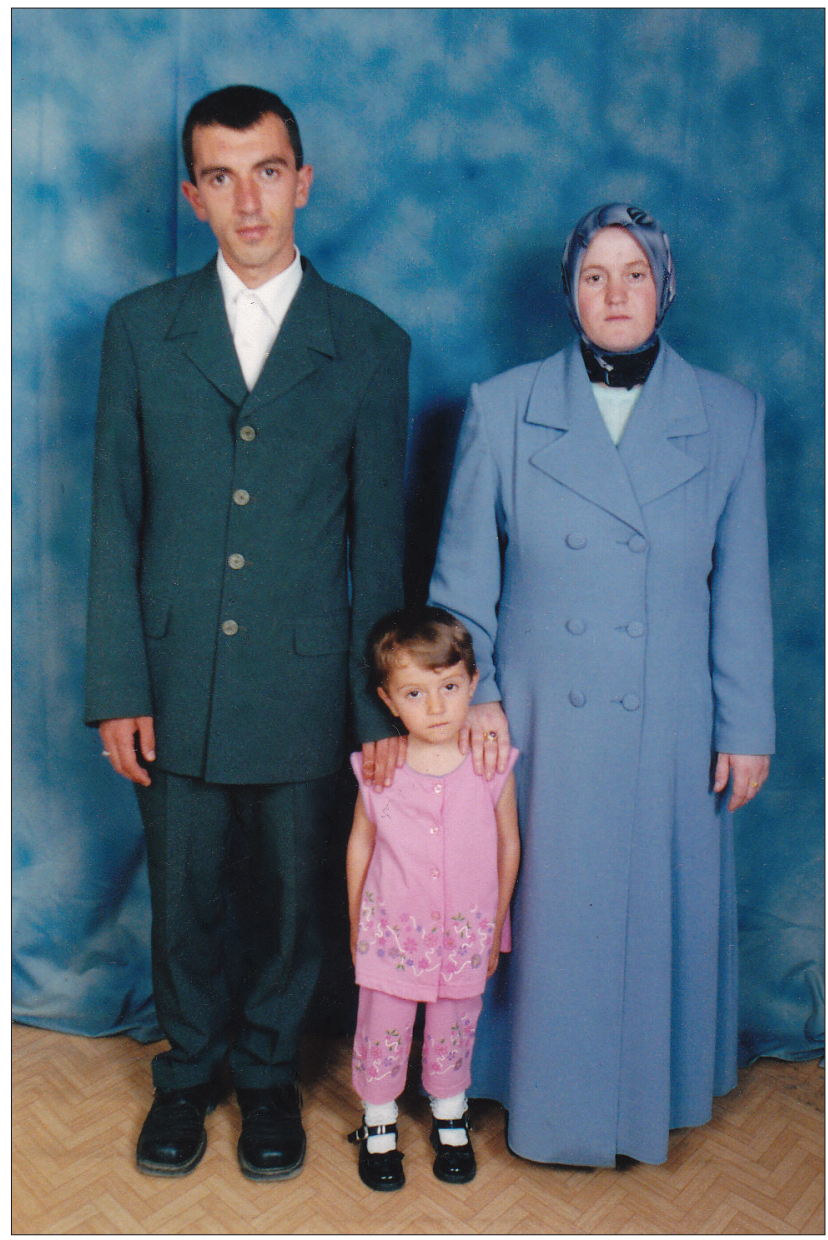

Figure 1. Turkish family. Nedelino, Southern Bulgaria, 2002.

considered a political instrument for construction of "a new Bulgarian socialist" nation. It influenced different Turkish identification markers such as the myth of ethnic origin, language, name, religion, rituals etc. The "Revival process" started June 19, 1984. The document compiled by the Politburo of the Central Committee of BCP 
stated that "differentiation of Bulgarian Turks, manifestations of Turkish nationalism, religious fanaticism and everyday conservatism continue". The communist leaders decided "to accelerate the development of the districts with a compact mass of Bulgarian Turks, to settle specialists in those regions, to develop the Turkish intelligence, to promote the system of mixed marriages, to impose communications in the Bulgarian language in public places and to suspend the constructions of new mosques" (Assenov 1991; Tsvetkova 2000). December 10, 1984 the Ministry of the Interior provided instructions to start renaming Bulgarian citizens of Turkish origin in all the regions where such population lived. ${ }^{7}$

The next stage in the conducting of the so called "Revival process" was the replacement of Turkish names with Christian ones or, respectively, Slavonic names of the Bulgarian Turks first in the Southern and afterwards in the Northern Bulgaria as well. ${ }^{8}$ The campaign itself started around Christmas in 1984. It happened in the same manner everywhere - the villages were surrounded by the army and militia, leaving was forbidden, telephone connections were cut off, identity papers were taken away from people and they were compelled to sign declarations stating that they did not have any relatives in Turkey and that they did not want to emigrate and that they voluntarily changed their names (Stoyanov 1998: 163). Enrolment forms were handed over for the selection of a new name. In areas where people found out about the change of the names beforehand, they ran into forests and mountains and hid for several days but the cold weather forced them to go back and obey the police (AIEM No. 574-III: 33). In some parts of the country, Turkish population organized mass protests against the renaming, but in others everything happened fast and without incidents. The Turkish resistance against the change of the names resulted in conflicts with the army and the militia and some people were even killed. Others died as a consequence of mental cruelty during the renaming. Those Turks, who managed to avoid imprisonment, were dismissed and settled separately inside or outside of the country (AIEM No. 574-III: 28, 35-36). In that manner, the names of over 310,000 people were changed. ${ }^{9}$ Sometimes even gravestones with Turkish or Arabic names were replaced. 
The change of names was followed by prohibiting such things as speaking Turkish in public places, practicing Islamic customs and rituals, listening to Turkish music and wearing traditional Muslim clothing etc. as a way to incorporate Turkish population into "the socialist way of living" (Eminov 2000; Stoianov 1998).

After carrying out the so called "Revival process", attempts were made for ideological justification. February 1988 "Theses on the Revival Process" were presented. It was noted that this was "a process of revival, clarification and enhancement of the Bulgarian national consciousness" (Zagorov 1993: 60). Bulgaria declared that all the Muslims were inheritors not of the "colonizers Turks, but of Bulgarians forcibly Islamized in the course of Turkish yoke". ${ }^{10}$ An ideological connection was made to Bulgarian national Revival started by Paisiy Hilendarski and his "Slavonic Bulgarian History" in 1762. The communist ideology spoke of a new contemporary Revival of that part of the Bulgarian people, that had been torn away from the main Bulgarian ethnos because of historical circumstances and who had been Islamized and had started to speak the Turkish language. The role of the ethnos in regard to identity determination was suggested. The idea of one nation state was maintained by viewing nation and nationality as overlapping: "the measure for ethnic belonging is the connection with the Bulgarian nation.... Bulgarian nation is formed on the ethnic cultural inheritance of one nationality - the Bulgarian one" (Zhivkov 1988). In this manner, the nation itself was identified with the dominating ethnos ignoring the variety of its ethnic ingredients. To attain the idea of a unified Bulgarian nation, it needed to be proven that the Turkish population belongs to the Bulgarian ethnos. The process of Revival is a "reinstatement, clarification and ratification of Bulgarian national consciousness in all those Bulgarians with proven Bulgarian origin whose forefathers and ancestors were converted to Islam during the yoke. In a wide sense, this is a process that reinstates the moral and political unity of the nation and contributes to the building up of the Bulgarian socialist nation" (Petrov 1988).

The common ideological formulations contributed to the appearance of a new exonym. The communist power introduced the term of "citizens with reinstated names". The propaganda spoke of "Islamized Bulgarians", emphasizing in this manner the forcible 
imposition of Islam (Krysteva 1998). The other name - "Bulgarians with different degree of patriotic consciousness, of religious convictions"11 - introduced the idea of different degrees of devotion to the Bulgarian state.

Undoubtedly those dramatic events reflected on the contemporary Turkish religious identity and behaviour visible in three main trends:

- Strengthening the role of religion and a return of religiosity (the process of re-Islamization or revitalization of Islam);

- Rejection of religion as an ideology (atheistic ideas);

- Situational attitude related to the manifestation of hidden religious beliefs and behaviour according to the given situation or interlocutor.

A starting point for the research is the EURO 2000 Survey about the depth of religious faith in Bulgaria. According to its data, just $28 \%$ of the Turkish population is deeply religious, $47 \%$ is religious to some extent, and 19\% is mostly unreligious. (Kanev 2002:77) ${ }^{12}$

\section{Re-Islamization or revitalization of Islam}

The violent assimilation and the restrictions imposed upon the Turkish minority provoked a process of return to the Islamic religion after the fall of the communist regime in 1989. The resistance forces of the group were awakened and the community aspired to find out the truth about its origin, to go back to religion and to reinstate the forgotten traditions. The people started not only to feel but also publicly declared their belonging to the Turkish and Muslim community. Generally, at the end of communist regime and at the beginning of democratic changes in Bulgaria, the representatives of the Turkish community restored or more precisely "clarified" their Turkish and Islamic ethnic, religious and cultural self-consciousness.

On the other hand, the open borders and free movement and migration between Bulgaria, Turkey and Western countries started the invasion of Islam in Bulgaria. Turks were influenced by different Islamic teachings and schools, some of them coming from Saudi 


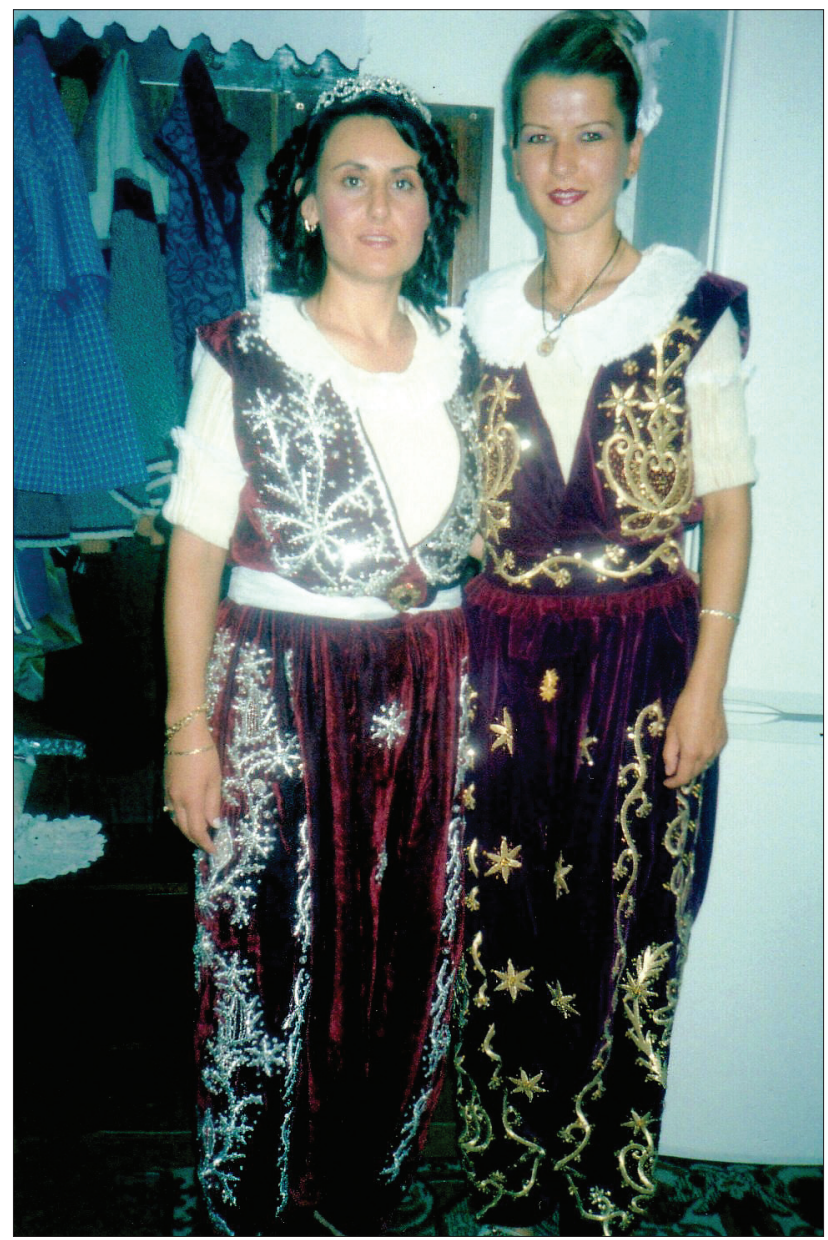

Figure 2. Alevi girls in tradition clothes. Mogilets, Targovishte region, Northern East Bulgaria, 2006.

Arabia, and very often they made their own choice regarding which Islamic school they belong to. 


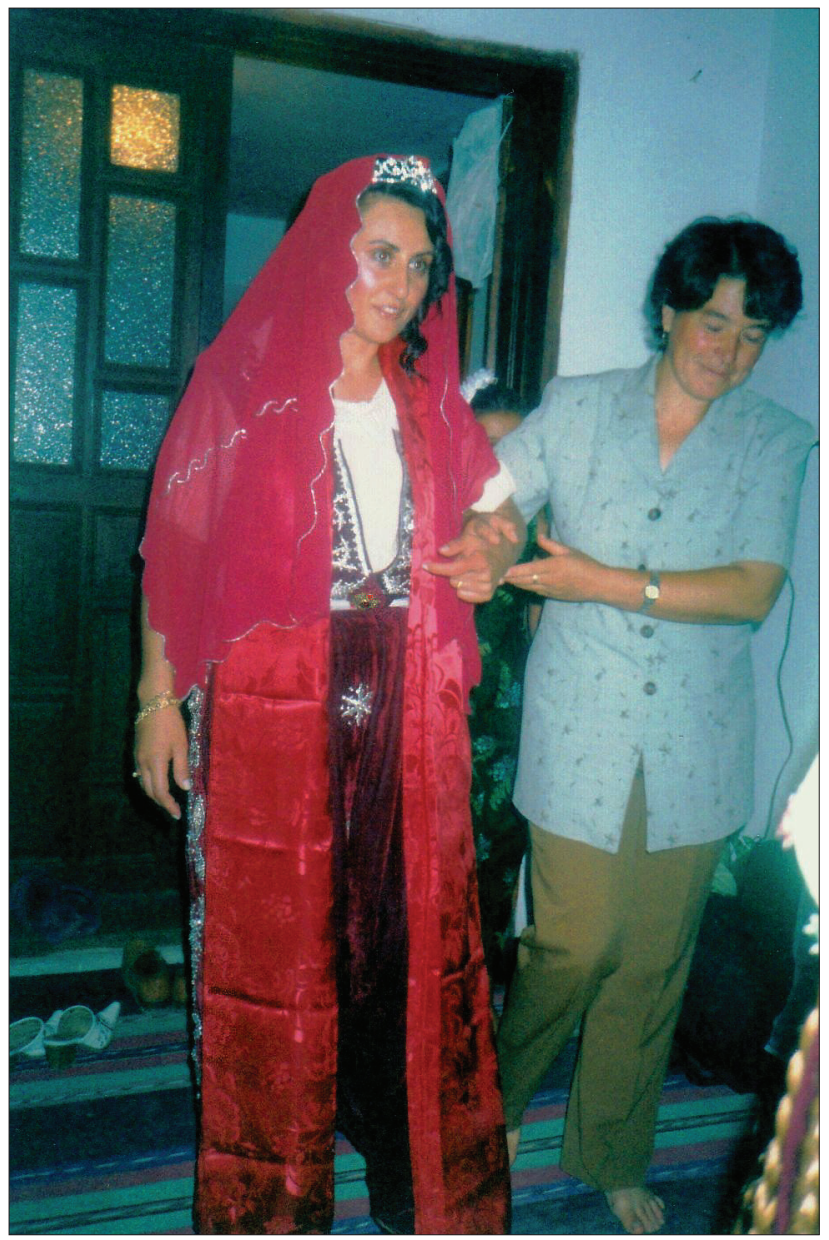

Figure 3. Alevi`s kana gecesi (the night of the kana). Mogilets, Targovishte region, Northern East Bulgaria, 2006.

Formally the process of Islamic revitalization is visible in the reinstatement of the "Turkish-Arabic names". After long debates and inspired by the BCP nationalist protests, the Act of the Reinstatement of Muslim Names was voted on March 5, 1990. By March 1, 
1991, more than 600,000 applications were processed and approved (Kynev 1998: 67-117).

In order to provide religious education and to train future Islamic spiritual leaders, the Islamic College at the Office of the Chief Mufti in Sofia is established in 1990. Later on, three secondary Islamic schools (situated in Ruse, Shumen and Momchilgrad) were founded in the country. ${ }^{13}$ A lot of young Turks received opportunities for religious studies abroad in Turkey, Iran or in Arabic countries.

Elective classes in Islam were introduced in public schools in 2000. Students used textbooks suggested by the Chief Muftiate and approved by the Ministry of Education. The classes were conducted in the Bulgarian language once a week and they were funded by the muftiate. According to official statistics of the Chief Mufti's Office in Bulgaria, a total of 3,372 students attended classes in Islam at elementary schools in 2011. 2012/2013, classes in Islam were taught in 27 schools around the country (Merdjanova 2013A: 471).

After 1989, most of the Turks, who up to that time did not know the Islamic norms, studied them and commenced to fulfil them zealously. Free courses of Koran were organized in every bigger Turkish village. The Koran has been translated into Turkish and Bulgarian. Many people, in particular the younger population, started to read the Muslim holy book. The prohibition of the Muslim customs and rituals during the communist regime and especially during the Revival process generated the public participation in them after the fall of the communist regime. The mass rituals, such as public circumcisions, were organized enhancing the belonging to the Muslim community:

We have a program of mass circumcision of Muslim children. This is a new bloodless method practiced for many years - with lazar...A special doctor is appointed by the Mufti. According to the Muslim religion, Mohammed was born circumcised and all Muslims should be circumcised.

The Muslim denomination undertakes the expenses and gives special clothes to the children. It also gives kourban, distributes food, and makes a special prayer for the health of the children. Each child receives a gift - a toy car or a knife. The Mufti finds sponsors for the circumcision. (AIEM 642-III: 20) 
Many Turks started to learn how to do the five-day prayer and fast during Bayrams. Now it is typical for Turkish villages to organise "iftar sofrasa" (ritual dinner during Ramazan fast) gathering all people irrespective of their religious belonging: "We organize iftar, not for the poor but for understanding between religions. We invite priests, Christians, important persons to show that people can live together" (AIEM 642-III: 35).

In view of the fact that most of Turkish people are builders, they opened or reconstructed the old mosques demolished during the communist regime. The renovation of türbes and tekkes buildings and construction of new religious centres is also visible in many regions with Turkish population. The main financial support comes from abroad, from the World Muslim League and a number of Islamic charity organisations and funds (mostly in the Middle East and Iran) (Marushiakova \& Popov: 43) as well as from emigrants in Turkey and Western Europe. By 1997 there were 1,041 functioning mosques in the country. According to official statistics of the Chief Mufti's Office in Bulgaria, the total number of functioning mosques in the country in 2011 was around $1,200 .{ }^{14}$ Those massive and impressive buildings have not just practical functions but, according the agents, they are a kind of demonstration and a visible presentation of their "Turkishness" especially in the mixed regions.

The process of re-Islamization is more visible in women's clothing. After 1989, many of them, especially those in small villages, wear shalwars and headscarves. Many Turkish girls and young women in Bulgaria put on headscarves for religious ceremonies (such as Mewlids or funerals) or when visiting mosques and other Muslim places such as türbes.

The emigration and life in the Western European countries with large Muslim minorities also contribute to the strengthening of religious faith and practices. Some of the emigrants who work in countries like Germany, Holland, Belgium and France indicated that they learned a lot about their own religion during their stay abroad. Some of the Turks are impressed by the behaviour of the local Muslims in the European Union: "In Belgium they are a long way ahead of us. Can you imagine how many young people go to their mosques and how many things they know?" (AIEM 642-III: 38). During their life in emigration, a part of the Turks follow Islamic 


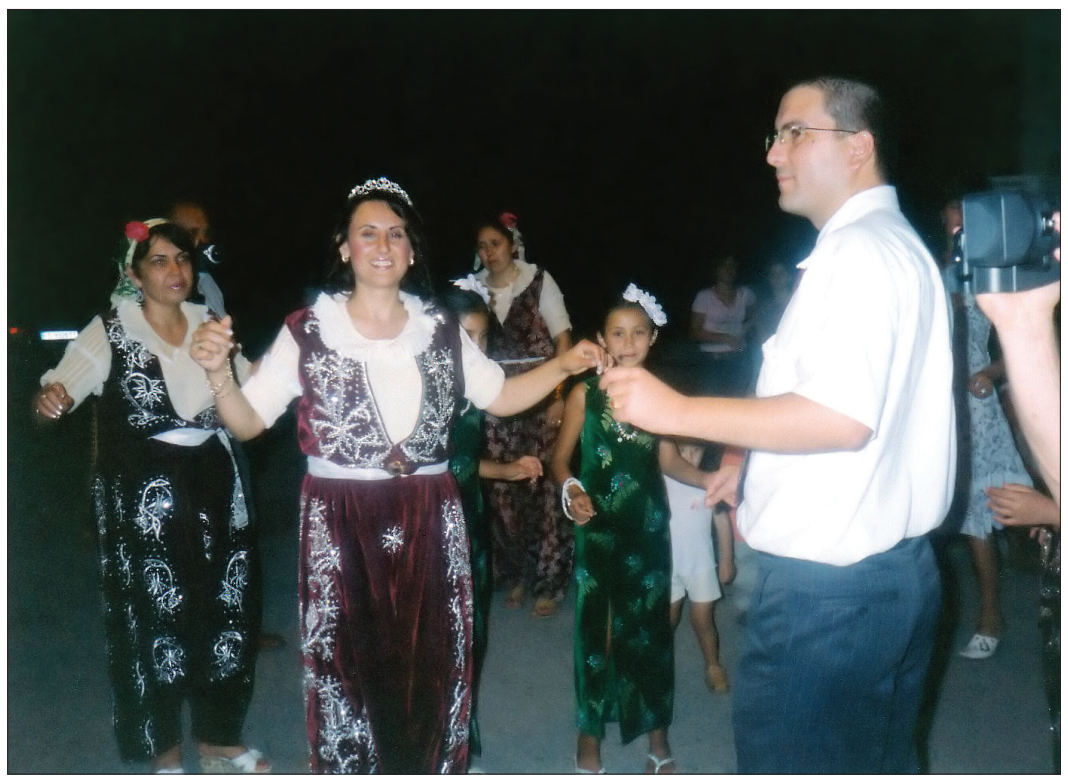

Figure 4. Alevi`s kana gecesi (the night of the kana). Mogilets,

Targovishte region, Northern East Bulgaria, 2006.

Figure 5. Nikah (religious marriage). Kardjali, Southern Bulgaria, 2006.

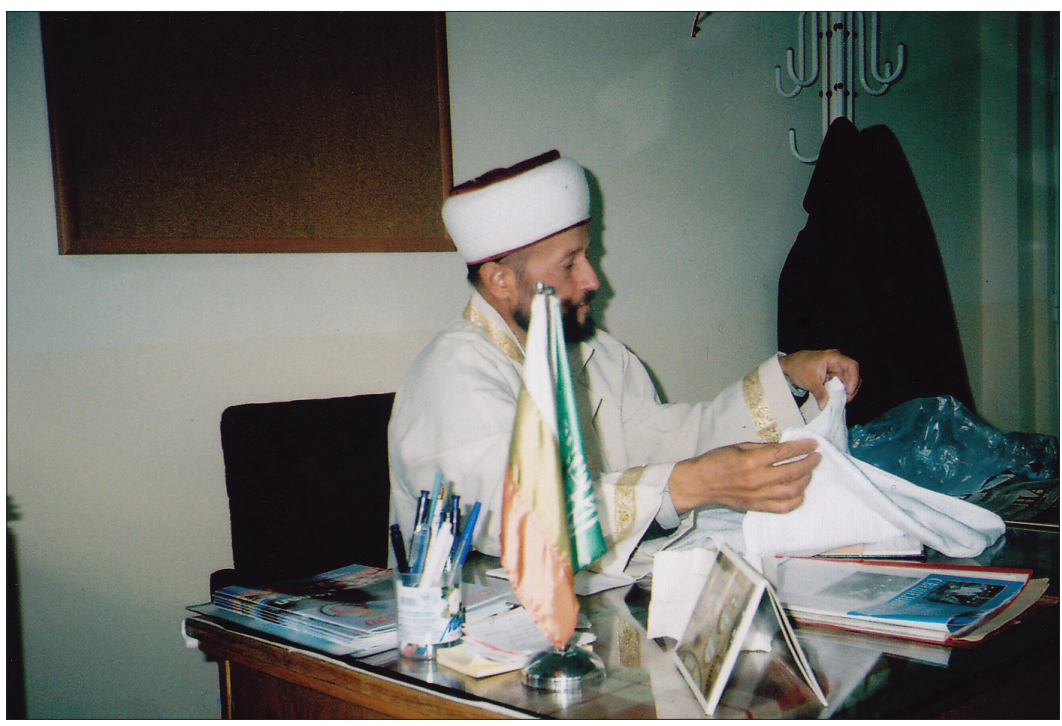




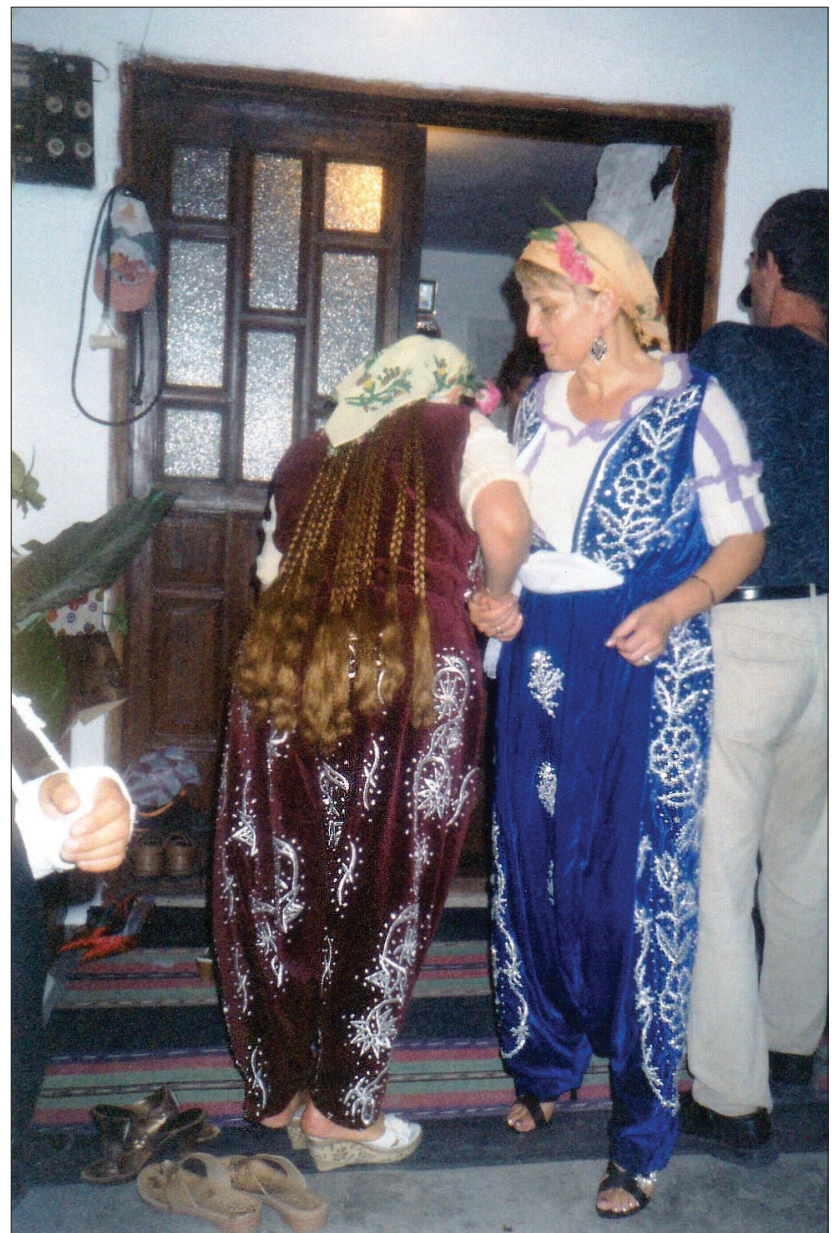

Figure 6. Alevi`s kana gecesi (the night of the kana). Mogilets, Targovishte region, Northern East Bulgaria, 2006.

norms and practices, often almost indiscriminately, according to their own preferences and according to the specifics of the religious school which they visited. 
After returning to Bulgaria, they continue to practice Islam and even demonstrate their Muslim identity through some visible markers such as beards in "Arabic style" or by carrying Shià religious symbols such as "Ali's sword". Some Turks insist on their wives being veiled as a demonstration of their confessional belonging. Others get tattoos with Islamic symbols or words: "I told the boss: "We are Muslims. Let's write: "Bismillah ir-Rahman ir-Rahim". Might not be in conspicuous position" (AIEM 642-III: 31).

The fieldwork materials from 1999 to 2013 show that the process of "Islamic revitalization" is typical mainly for the older generation and especially for retirees. Only the elderly people attend mosques frequently and strictly observe Islamic injunctions and taboos (the prohibition to eat pork and drink alcohol): "Father went to pray. Because if he does not go, he's an old man, people should say: "That's a shame"' (AIEM 642-III: 18).

After the fall of the communist regime, predominantly older women renewed the tradition of praying together at home. Usually on Thursdays, they gather in one house and organize a Mawlid prayer in memory of deceased relatives. After that, they make and distribute katmi ('pancakes') or sweets for the dead relatives.

It is noteworthy that those Turks who were supporters of the communist ideology in Bulgaria became zealous Muslims and started to practice Islamic rituals after the fall of the communist regime. On the other hand, re-Islamization is typical for a small number of young people who learned abroad and who are supporters of Islamic traditions. Their knowledge of Islam, however, often led to conflicts with the older people who have their own ways of practicing religion.

\section{Secularisation process}

"Secularization" means "a process of declination of the influence of religion" and it is related to atheism. According to Zuckerman, modern Bulgaria is remarkably similar to Western Europe in terms of a general decline in religious belief, despite its lack of state-church separation. For instance, in 2006, Bulgaria ranked 17th out of the 50 most atheist countries in the world, joining the overwhelmingly European top 20. The study found that $34-40 \%$ of the Bulgarian population was atheistic, agnostic, or non-religious (Zuckerman 
2009: 951; Ghodsee 2009: 233). According to another study by Kanev only $13.7 \%$ of respondents wanted their children to regularly attend "church/mosque/synagogue." However, 52.4\% of Bulgarian Christians and $52 \%$ of Turks living in Bulgaria said that they wanted their children to be religious "just as a cultural identity." Another nationally representative survey conducted in 1999 found that $96 \%$ of ethnic Bulgarians said that they were Christians and 98\% of the Turkish minority declared themselves Muslim (Ghodsee 2009: 233). In analysing these results, the Bulgarian scholar Petar Kanev concluded that religion in Bulgaria is "rather peculiar" and argued that being "religious" and believing in God had little to do with each other. Despite all of this, even after 1989, since when the world Islam has been methodically seeking to gain back its lost positions among Muslims of Bulgaria, the percentage of the local Turkish population remaining atheist is not small (Kanev 2002: 84).

Those statistics support my fieldwork finds among representatives of the Turkish minority. Even though there are free religious courses and Islamic propaganda in Bulgaria, majority of Turks have limited knowledge of their own religion, Islamic beliefs and practices and only a small number of them follow the prescriptions of the Koran and Sheria. As an agent told: "I believe in Allah, but I haven't got time to pray."

Secularism is particularly visible in the way of life. After the first peak of religious behaviour in 1990s and even though having a mosque in each neighbourhood or village is considered necessary, the research showed that the mosques are usually attended by elderly men who are daily anointed not only as a duty to Allah, but as a kind of fun. For example, in 2013 the new mosque in Chernoochene village (near Kardjali in South Bulgaria) was visited by a few old men during the week. The biggest part of Turkish population visits and prays in the mosques on Fridays only or during the Ramazan or only on Bayrams. Another Turk added: "Here in Kurdzhali young people still come to the big mosque, but if you go to the villages you will only see elderly men. Very often you meet young Turks, who don't know anything [about Islam - Mila Maeva's note]." (AIEM 642-III: 38); "The young people are not religious" (AIEM 642-III: 18).

Secularization is visible in everyday Turkish culture. Due to the long atheistic propaganda and the strong assimilation process, 


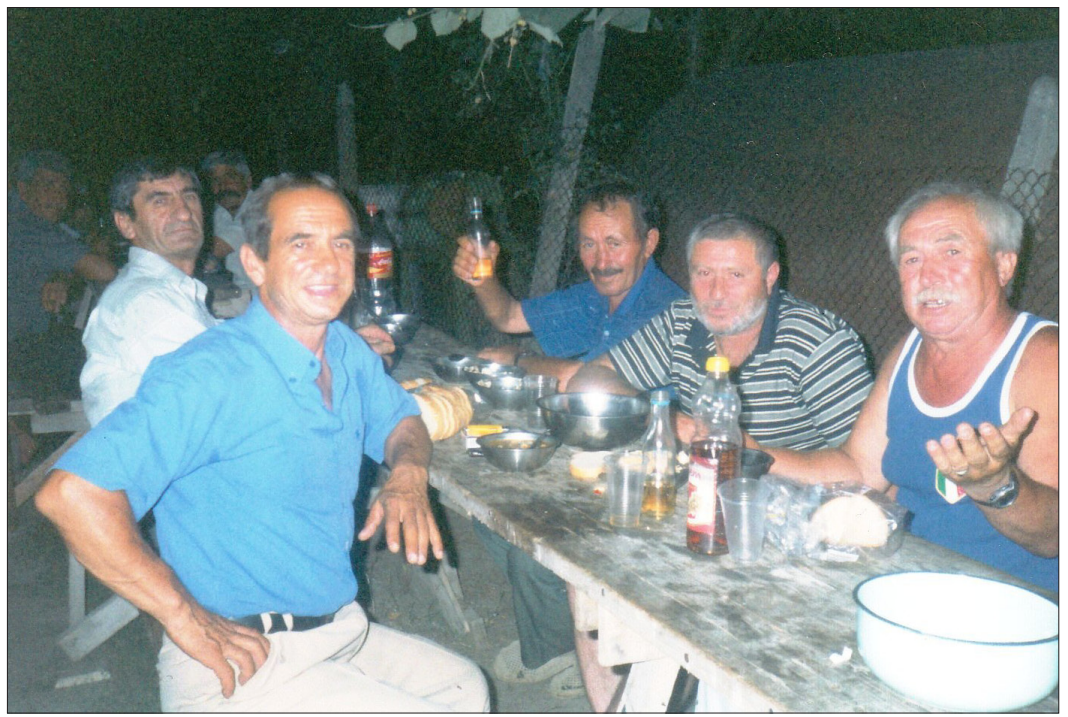

Figure 7. Alevi`s kana gecesi (the night of the kana). Mogilets, Targovishte region, Northern East Bulgaria, 2006.

Figure 8. Nikah (religious marriage). Kardjali, Southern Bulgaria, 2006.

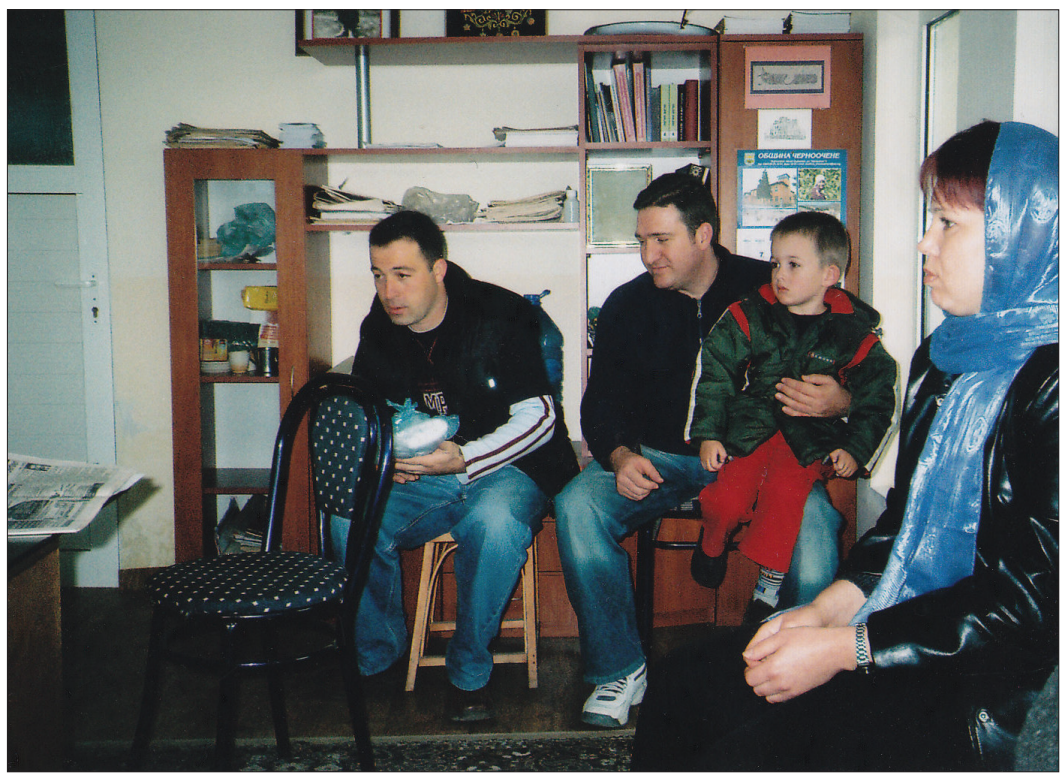




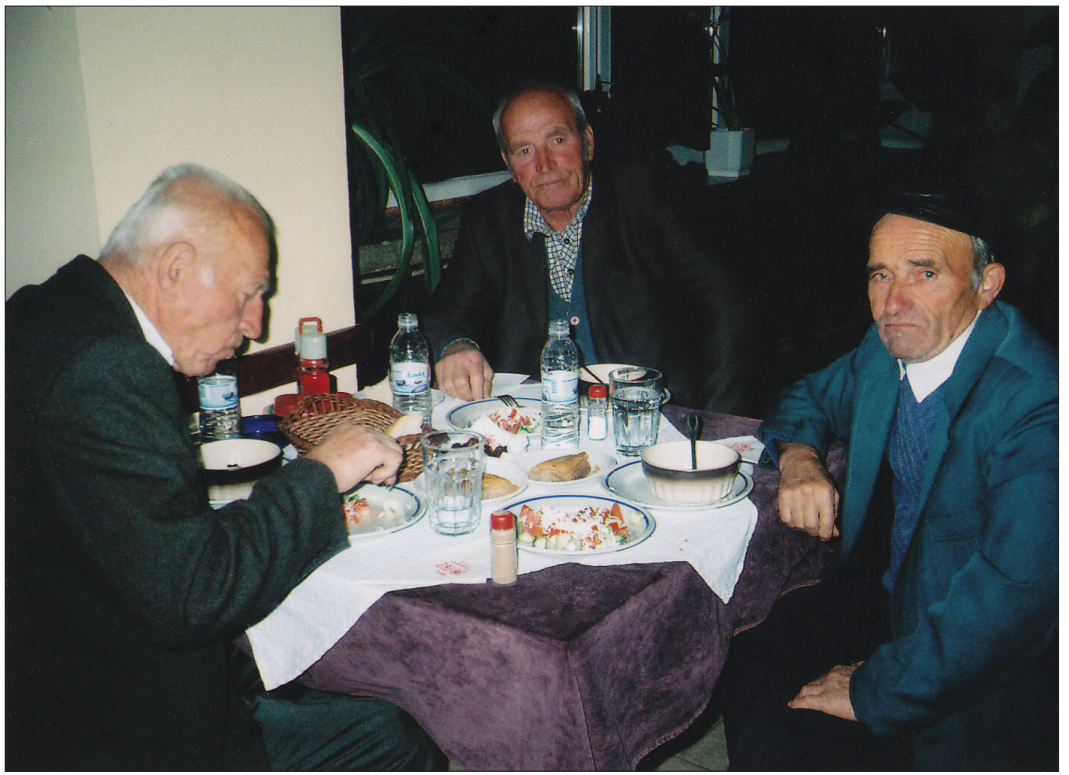

Figure 9. Iftar sofrasi (ritual dinner during Ramazan fast). Kardali, Southern Bulgaria, 2006.

numerous Bulgarian and Christian cultural elements entered into the Turkish culture and they are still alive there. Some of the representatives of the Turkish minority in Bulgaria keep on using their two names (Muslim and Bulgarian ones) as an easier way to emigrate to Western Europe and to cope with Muslim negativism in the European countries (see Maeva 2007). Many Turks continue practicing various Bulgarian customs and rituals. For example, they celebrate the holiday of wine (St. Trifon's day) on February 14 or wear martenitsi (red and white thread symbolizing the start of the spring on March 1). Nowadays, the young Turks as well as young Bulgarians celebrate the St. Valentine's Day (February 14) buying red roses and red lingerie for their girlfriends or wives.

For many Turks, the "permitted" and "forbidden" foods do not exist. Even though there is a well-organized system of halal shops, especially in mixed regions, a lot of my agents continue to eat non-halal food. The restrictions of pork and alcohol are just optional practices. 
The situation is the same with the dress code - many young Turkish girls and women dress in a fashionable way without headscarves.

The modern influences are also visible in the most conservative rites such as funeral rituals - for example some Turks make obituaries (with flowers) and bury their deceased with clothes and coffin, practices connected to heavy conflicts with religious people such as imams. The same disagreements create the refusal of local imams to bury people who had not changed their imposed Bulgarian names back to Islamic ones. They insist also on removing headstones with photos ${ }^{15}$ of the deceased, an Orthodox practice, from Muslim tombs (see Broun 2007).

The reasons for this tendency of secularism or "laicization of Islam" (see Kalkandjieva, Schnitter 2007) in Bulgaria are both internal and external. Reasons for this can be the limitations of religious knowledge due to family environment, the strong influence of secular education, the long period of atheistic views and ideas imposed by the communist regime, and spiritual weakness of institutions during the totalitarian rule. The limited role of religion in the world also has a strong influence. Many Turks often explain their secularization with communist rule and the prohibition to practice Islam. It is clear that secular education, economic development and social mobility reduce the influence of religion too.

\section{Situational Religiosity/Secularism}

In many cases, Turks in Bulgaria are divided between religiosity and secularization depending on the situation they fall in. The general impression is that the deep religiosity appears in families with older people or in situations of individual or community crisis, while secular behaviour points to such outsiders as Bulgarians, Christians or even younger people.

Some of the Turks observe the Muslim orders and tradition during sacred periods. For example, one of my agents told that he rejects using pork and alcohol only during the holy month of Ramazan. According to other experiences shared with me, a family prepared barbecue with pork meat in the garden because the old grandmother did not allow it in the house. A third agent expressed his own view on religion: "I have a liberal attitude towards Islam; it means that 
I decided what to do and not do. So I do not do namaz five times a day, but I keep oruch [the Muslim fast]. As a student, I did, but now I'm a bit lazy" (AIEM 642-III: 27).

The observation of Islamic norms and practices happens in crisis situations, such as someone's death, because the life cycle rites are one of the most conservative cultural elements. During that period, the majority of Turks return to the Islamic traditions and fulfil them zealously as a way to send their relative successfully to the life after death.

The return to the Muslim traditions is also evident in some other cases, such as safely coming home from work abroad (gurbet). The arrival from emigration to the birth place is celebrated by sending prayers to Allah. For example, upon their return from abroad, Alevi Muslims from the Omourtag region visit Ali baba's türbe located in the Balkan Range. The event usually gathers a few migrant workers and their relatives. A Thursday or a Sunday are considered most appropriate for this purpose, those two being sacred days for them. The ascension of the mountain peak is accompanied by prayers and lighting of candles in gratitude for the successful gourbet and in hope of a future easy journey. An animal is slaughtered, roasted and eaten on spot. There has been no indication as to the species of the animal. Often it is considered of no consequence. A variety of this with the Sunni is the shukyur kourban. This is again a thanksgiving of sorts for the help of Allah during the stay abroad. The choice of sacrificial animal follows the prescriptions for korban: "Muslims prefer a black ram" (AIEM 642-III: 26). The family of the migrant worker does not eat from the korban. It is entirely donated either as raw or boiled meat and the hide of the animal or the money they obtain through its sale is donated to the local mosque. Money donations are common among those who have returned home safely from gourbet. The sums increase if the donation is done during the month of the Ramazan or any of the Bayrams. The korban and the money donations are a proof of the significance attributed to the return to the motherland and the native place. But they are also a way to demonstrate belonging to the confessional community and to preserve the Islamic identity of the migrant workers (Maeva 2007).

As N. Ragaru mentioned, Turks in Bulgaria manage to combine a secular, consumerist lifestyle, and devotion to modern technol- 
ogy with the knowledge and observance of religious prescriptions, according to a social or cultural situation (Ragaru 2001). Many of them shared the vision that ethnic and religious affiliation overlap: "Community accepts that as a Turk you are Muslim" (AIEM 642-III: 38 ). For that reason, the majority of the Turkish population think of themselves as Muslim and even as "good" Muslims.

Common opinion is that Islam in Bulgaria is specific, different from Islam in Europe and Arabic countries. Turkish population in the country supports the thesis about Balkan Islam as more tolerant and as a "genuine European Islam", since its followers are autochthonous and largely secularized Muslims contrasted with a "non-European Islam" encompassing not only those countries with a Muslim majority, but also the Muslim migrants who settled in Western Europe in the second half of the twentieth century (Bougarel 2005: 147).

Generally, Turkish minority in Bulgaria treats religion more as a cultural tradition and identity rather than a sacred communication and spiritual commitment (see Ghodsee 2009: 232-233).

\section{Conclusion}

The changes in the Turkish religious affiliation in the last 24 years have their roots in the communist past, the policy of the Bulgarian Communist Party and in the so called "Revival process". Other important factors are the long period of transition, emigration waves to Turkey and Western Europe and the emergence of new Islamic studies. Despite the strong process of "re-Islamization" of Turks in Bulgaria, the activities of Islamic organizations (mostly Turkish, less Arabic ones trying to attract Turks to their side), or the religious propaganda conducted by emissaries from abroad, the majority of Turks in Bulgaria are secularly disposed. The fundamental reason for this is the atheistic attitude of Bulgarian society as a whole. The overlapping of ethnic and religious identity - "Turk" means "Muslim" - has been primary among the representatives of the Turkish minority during the last 24 years. Despite the processes of borders opening, globalization and Islamic propaganda, belonging to the universal "Umma" community is far behind the primordial markers such as ethnic origin and cultural traditions. 


\section{Acknowledgement}

A part of the research was conducted in the framework of the project "Dynamics of the processes of return and reintegration of Bulgarian emigrants" (DMU 03/52, 12.12.2011), financed by the Bulgarian science fund.

\section{Notes}

${ }^{1}$ About the origin and settlement of Turkish population on the Balkans see Zhelyazkova 2001 and Eminov 2007.

${ }^{2}$ http://censusresults.nsi.bg/Census/Reports/2/2/R7.aspx

According to the experts, representatives of the Turkish-speaking Gypsies and Bulgarian Muslims (Pomaks) are identified as Turks too (Marushiakova \& Popov 2004: 57).

${ }^{3} \mathrm{http} / / /$ censusresults.nsi.bg/Census/Reports/2/2/R10.aspx

A small part of Turks - Gagauz - are Orthodox Christians. In Bulgarian science there is a long discussion about the origin of Gagauz. Many scholars support the thesis that the Gagauz community with Bulgarian origin lost their Bulgarian language during the Ottoman rule. The second theory claims that they are the descendants of Turkic people who came from Asia Minor and settled on Bulgarian territory during the Ottoman Empire (see Eminov 2000; Karpat 1991; Mateeva 2006; Stamenova 1998).

${ }^{4}$ Officially that population was qualified as "Shià Muslims" by national Census in 2011.

5 Report "Za systoianieto, niakoi problemi i zadachi za po-natatyshnoto razvitie na vyzroditelniia proces" $1987-\mathrm{CDA}$, f. 1b, op. 63, a e. 2, s. 6-9.

${ }^{6}$ op. cit.

${ }^{7}$ Archivse of Bulgarian Interior Ministry, a report of the operation from December 10, 1984.

${ }^{8}$ V. Ozkan qualified the Revival process as "Namecide process" (Ozkan 2012).

9 Report by Georgi Athanassov concerning a meeting with communist leaders on January 18, 1985, Central State Achive, Sofia (CDA, ch. 1b, op. 63 , a. e. 72 ).

${ }^{10}$ Report by Georgi Athanassov concerning a meeting with communist leaders on January 18, 1985 - Prava i svobodi, br. 4, 1991, 9. 
${ }^{11}$ CDA, ch. 147 b, op. 2, a. e. 2989, l. 6 .

${ }^{12}$ Other research done in 2011 showed that religious Muslims in Bulgaria are $28,5 \%$, only $8,1 \%$ of them think that the one true religion exists, $41 \%$ never go to the mosque and 59,3\% never pray. On the other hand, $90 \%$ of Muslims circumcise their children and 96\% bury deceased according to Muslim traditions. (Ivanova 2011).

${ }^{13} \mathrm{http}: / / \mathrm{www}$. islamicinstitute-bg.org/

About relations between Grand Mufti and political parties and leaders in Bulgaria see Eminov 1999.

${ }^{14} \mathrm{http} / / / w w w . g r a n d m u f t i . b g / b g / a b o u t u s / 2009-04-20-14-58-33 . h t m l$

15 The perception that the deceased changes form of existence after death and looks different than in the earthly life dominates in the Islamic view.

\section{Sources}

AIEM - Archives of Ethnographic Institute with Museum, Sofia. CDA - Central State Archives, Sofia.

\section{References}

Aleksiev, Bozhidar 2012. Sedem miusiulmanski svetci ot Balgariia. Sofia: Akademichno izdatelstvo "Professor Marin Drinov".

Asenov, Boicho 1991. Vazroditelniiat proces proces i Darzhavna sigurnost Prava $i$ suobodi, pp. 5-9.

Biuksenshiuts, Ulf 2000. Maltsinstvenata politika v Bylgariia. Politikata na BKP kym evrei, romi, pomaci i turci (1944-1989). Sofia: IMIR.

Bougarel, Xavier 2005. Balkan Muslim Diasporas and the Idea of a "European Islam". Dulić, Tomislav et al. (eds.). Balkan Currents. Essays in Honour of Kjell Magnusson. Uppsala Multiethnic Papers 49. Uppsala: Uppsala University, pp. 147-165.

Broun, Janice 2007. Rehabilitation and recovery: Bulgaria's muslim communities. Religion, State and Society, 35 (2), pp. 105-138.

Eminov, Ali 1997. Turkish and other Muslim Minorities in Bulgaria. Institute of Muslim Minority Affairs, Book Series no. 6. London: Routledge. 
Eminov, Ali 1999. The Turks in Bulgaria: Post-1989 Developments. Nationalities Papers, 27 (1), pp. 31-55.

Eminov, Ali 2000. Turks and Tatars in Bulgaria and the Balkans. Nationalities Papers, 28 (1), pp. 129-164.

Georgieva, Ivanichka (ed.) 1991. Bylgarskite aliani (sbornik etnografski materiali). Sofia: Universitetsko izdatelstvo.

Ghodsee, Kristen 2009. Symphonic Secularism: Eastern Orthodoxy, Ethnic Identity and Religious Freedoms in Contemporary Bulgaria. Anthropology of East Europe Review, 27 (2) (Fall), pp. 227-258.

Ghodsee, Kristen. 2009. Muslim Lives in Eastern Europe: Gender, Ethnicity and the Transformation of Islam in Postsocialist Bulgaria. Princeton: Princeton University Press.

Grand mufti 2009. Glavno myufiistvo. Miusulmiansko ispovedenie. http://www.grandmufti.bg/bg/aboutus/2009-04-20-14-58-33.html (Accessed 11.08.2017).

Gramatikova, Nevena 2011. Neortodoksalniiat isliam v bylgarskite zemi. Sofia: Gutenberg.

Ivanova, Evgeniya 2011. V Balgariya nyama politicheski islyam. BalgarskoHelsinki Komitet.

http://www.bghelsinki.org/bg/novini//bg/single/prof-evgeniya-ivanova-vblgariya-nyama-politicheski-islyam/

Kalkandjieva, Daniela \& Schnitter, Maria 2007. Religion and European Integration in Bulgaria. Polzer, Miroslav, Devetak, Silvo, Toplak, Ludvik, Unger, Felix \& Eder, Maria (eds.). Religion and European Integration. Religion as a Factor of Stability and Development in South Eastern Europe. Proceedings of contributions from the Maribor Symposium 2005. Book series of European Academy of Sciences and Arts, Vol. 6. Weimar: Druck: VDG, pp. 351-376.

https://www.academia.edu/754973/RELIGION_AND_EUROPEAN_INTEGRATION_IN_BULGARIA (Accessed 11.08. 2017).

Kanev, Petar 2002. Religion in Bulgaria after 1989: historical and sociocultural aspects. South-East Europe Review, Vol. 2, pp. 75-96.

http://www.forost.lmu.de/fo_library/Kanev_Religion_in_Bulgaria_2002. pdf (Accessed 11.08.2017).

Karamihova, Margarita 2002. Prikazka za Osman baba [The Shrine of Osman Baba]. Sofia: Akademichno izdatelstvo "Professor Marin Drinov". 
Karpat, Kemal 1991. The Turks of Bulgaria: The History, Culture, and Political Fate of a Minority. University of Wisconsin, Madison: University of Wisconsin Press.

Kynev, Krasimir 1998. Zakonodatelstvo i politika kym etnicheskite i religioznite malcinstva v Bylgariia. Krasteva, Anna. (syst.) Obshtnosti $i$ identichnosti $v$ Bylgariia. Interkulturni izsedvanii 1. Sofia: Petekson, pp. 67-117.

Krysteva, Neika \& Asenov, Bojcho 1993. Poturchvane II. Sofia: [s.n.].

Krysteva, Anna 1998. Identichnost i vlast: Komunisticheski i postkomunisticheski diskurs vyrhu malcinstvata. Krysteva, Anna (ed.) Obshtnosti i identichnosti. Interkulturni izsedvanii 1. Sofia: Petekson.

Maeva, Mila. 2007. New Migration Waves of Bulgarian Turks. Marushiakova, Elena (eds.). Dynamics of National Identity and Transnational Identities in the Process of European Integration. Cambridge: Cambridge Scholar Publishing, pp. 224-247.

Marushiakova, Elena \& Popov, Vesselin 2004. Muslim Minorities in Bulgaria.

http://academos.ro/sites/default/files/biblio-docs/219/bulgaria_article0003. pdf (Accessed 11.08.2017).

Mateeva, Vania 2006. Gagauzite - oshte edin pogled [The Gagauzes: Yet Another View]. Sofia: Akademichno izdatelstvo "Professor Marin Drinov".

Merdjanova, Ina 2013a. Administering Islam in Bulgaria: legal and political aspects. Turkish Review, 3 (5), pp. 474-483.

Merdjanova, Ina 2013b. Rediscovering the Umma: Muslims in the Balkans between Nationalism and Transnationalism. New York: Oxford University Press.

Mikov, Liubomir 2005. Izkustvoto na heterodoksnite miusiulmani v Bylgariia (XVI-XIX v.). Bektashii i kyzylbashi/alevi. Sofia: Akademichno izdatelstvo "Professor Marin Drinov".

Özkan, Vildane (Vildane Shabanova Alieva) 2012. The Effects and Appearances of Namecide Process from Socialist to Post-socialist Bulgaria. ВІСНИК НТУУ «КПІ». Політологія. Соиіологія. Право, 4 (16) http://ela.kpi.ua/bitstream/123456789/3375/1/04_shab.pdf (Accessed 11.08.2017).

Population Census 2011. NCCEDI [National Council for Cooperation on Ethnic and Integration Issues] 
http://censusresults.nsi.bg/Census/Reports/2/2/R10.aspx http://censusresults.nsi.bg/Census/Reports/2/2/R7.aspx (Accessed 10.08.2017).

Poulton, Hugh 1993. The Balkans: Minorities and States in Conflict. London: Minority Rights Publications.

Ragaru, Nadege 2001. Islam in Post-Communist Bulgaria. An Aborted “Crash of Civilization?” National Papers, 29 (2), pp. 293-394.

Stamenova, Zhivka 1998. Gagauzi. Krysteva, Anna (ed.). Obshtnosti $i$ identichnosti $v$ Balgaria. II. Sofia: Petekston.

Stoianov, Valeri 1998. Turskoto naselenie mezhdu poliusite na etnicheskata politika. Sofia: Lik.

Trifonov, Staiko 1991. Strogo poveritelno! Pogled, Apr. 22, 1991, pp. 16-19.

Tsvetkova, Milena 2000. Balgarskata politika kam Vazroditelniia proces sled 1944 g. Mezhdunarodni otnoshenia, II.

Vishsch Isliamic Institut 2007. http://www.islamicinstitute-bg.org/ (Accessed 11.08.2017).

Yalamov, Ibrahim 2002. Istoriia na turskata obshtnost v Bylgariia. Sofia: IMIR.

Zagorov, Orlin 1993. Vazroditelniiat proces. Teza, antiteza i otritsanie na otritsanieto. Sofia: Orlin Zagorov.

Zhelyazkova, Antonina 2001. Bulgaria in Transition: the Muslim minorities. Islam and Christian-Muslim Relations, 12 (3), pp. 283-301.

Zhivkov, Todor 1988. Etnokulturno razvitie na Vazroditelniia protses. Yankov, Georgi; Dimitrov, Strashimir; Zagorov, Orlin (eds.). Problemi na razvitieto na bylgarskata narodnost $i$ naciia. Sofia: BAN, pp. 127-143.

Zuckerman, Phil 2009. Atheism, Secularity, and Well-Being: How the Findings of Social Science Counter Negative Stereotypes and Assumptions. Sociology Compass, 3 (6), pp. 949-971.

https://dx.doi.org/10.1111/j.1751-9020.2009.00247.x 


\section{ELM Scholarly Press \\ SATOR 18}

http://dx.doi.org/10.7592/Sator.2017.18

\section{BALKAN AND BALTiCUM}

Current Studies in the Postsocialist Space

Edited by

Ekaterina Anastasova and Mare Kõiva

Tartu 2017 
Editors and compilers: Ekaterina Anastasova, Mare Kõiva Series "Sator" editor: Mare Kõiva

Language editors: Liisa Vesik, Lii Liin

Cover photo: Jaak Kikas, 2017 "Autumn in Tartu"

International committee

Tiiu Jaago (Tartu University); Reet Hiiemäe (Estonian Literary Museum); Mare Kalda (Estonian Literary Museum); Tarmo Kulmar (Tartu University); Nikolay Kuznetsov (Estonian Literary Museum); Aado Lintrop (Estonian Literary Museum); Emily Lyle (School of Scottish Studies in Edinburgh); Mirjam Mencej (Ljubljana University); Jonathan Roper (Tartu University); Marju Kõivupuu (Tallinn University); Ülo Valk (Tartu University); Tatjana Vladõkina (Institute of Udmurtian History, Language and Literarture, Izhkar); Irina Vinokurova (Institute of Karelian History, Language and Literarture in Petroskoi); Ergo-Hart Västrik (Tartu University)

Supported by Estonian Academy of Sciences, Bulgarian Academy of Sciences, the Centre of Excellence in Estonian Studies (CEES, European Regional Development Fund) and is related to research projects IRG 22-5 (Estonian Research Council).

\section{$\boldsymbol{C} E \mathbf{E} \times \begin{aligned} & \text { Centre of excellence } \\ & \text { in Estonian Studies }\end{aligned}$}

Series "Sator. Artikleid usundi- ja kombeloost", 18 http://www.folklore.ee/rl/pubte/ee/sator/sator18/

ISSN 1736-0323 (online)

ISBN 978-9949-586-58-5 (printed)

ISBN 978-9949-586-61-5 (online) ISSN 1406-2011 (printed)

DOI: 10.7592/Sator.2017.18

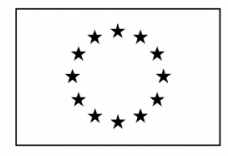

European Union European Regional Development Fund

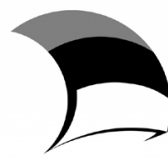

Investing in your future

\section{EUROPEAN UNION}

Regional Development Fund

Investing in your future
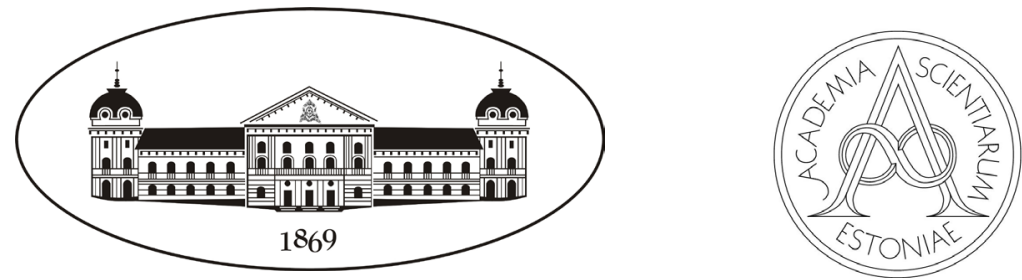


\section{Contents}

Preface

Mare Kõiva, Ekaterina Anastasova

CONSTRUCTING IDENTITY AND SOCIAL TIES

Ethnographic Studies on the Montenegrin

Festive Costume as a National Symbol

Sofiya Zahova

Social Ties of Bulgarians and Rudari in the Mediterranean Countries

Magdalena Slavkova

\section{RECASTING RELIGION AND \\ RELIGIOUS IDENTITY}

Contemporary Development of the Akyazili

Baba Tekke / St. Athanasius in Bulgaria

Yelis Erolova

Turkish Religious Identity in Bulgaria

94

in the Last Twenty-Four Years (1989-2013)

Mila Maeva

The Feast of Cyril and Methodius in Bessarabia and Crimea, Ukraine

Ekaterina Anastasova 
The Saints of Death in the Traditions

of the Balkan People

Rachko Popov

\section{CONSTRUCTING NEW SPIRITUALITY}

New Trends in the Study of Religion in Estonia -

Contemplations in the Grey Zone between

Religion and Science

Tõnno Jonuks

Constructing New Spirituality in Modernity -

the Case of the White Brotherhood in Bulgaria

Svetoslava Toncheva

Constructing Contemporary Periodical and

Occasional Rituals

Mare Kõiva

The Making of a Sacred Place:

221

An Example of Constructing Place Identity in the Contemporary Mentality

Reet Hiiemäe

\section{CHANGING TRADITIONS}

Bridge Over the Rainbow. Animal Burials and

Animal Cemeteries in Post-Socialist Estonia

Marju Kõivupuu

Simple Hide-and-seek at its Core: Play Features and the Game of Geocaching

Mare Kalda 